\title{
XI. Description of an air and a water-vault employed to equalize the discharge of air into a blast-furnace
}

\author{
Mr. David Mushet
}

To cite this article: Mr. David Mushet (1800) XI. Description of an air and a water-vault employed to equalize the discharge of air into a blast-furnace, Philosophical Magazine Series 1, 6:24, 362-364, DOI: 10.1080/14786440008677237

To link to this article: http://dx.doi.org/10.1080/14786440008677237

曲 Published online: 25 Jan 2010.

Submit your article to this journal $\pi$

Џll Article views: 2

Q View related articles $\sqsubset$ 
one of the molt effential parts has been taken away. Now fuch foffil or burned bones can no more be regarded as bone, than charcoal can be confidered as the vegetable of which it retains the figure and fibrous ftructure.

Bones which keep their figure after combution refemble charcoal made from vegetables replete with fibre; and cartilaginous bones which lofe their thape by the fame caufe may be compared to fucculent plants, which are reduced in bulk and thape in a fimilar manner.

From thefe laft experiments $I$ much queftion if bodies confifting of phofphat of lime, like bones, have concurred materially to form ftrata of limeitone or chalk; for it appears to be improbable that phofphat is converted into carbonat of lime after thefe bodies have become extraneous foffils.

The deftruction or decompofition of the cartilaginous parts of teeth and bones in a foffil tate muft have been the work of a very long period of time, unlefs accelerated by the action of fome mincral principle; for, after having, in the ufual manner, fteeped in muriatic acid the os hameri of a man brought from Hythe in Kent, and faid to have been taken from a Saxon tomb, I found the remaining cartilage nearly as complete as that of a recent bone. The difficult deftructibility of fubltances of a fomewhat fimilar nature appears alfo from the piercing implements formed of horn, which are not unfrequently found in excavations of high antiquity.

XI. Defcription of an Air and a Water-Vault employed to equalize the difcbarge of Air into a Blajt-Furnace. By Mr. David Mushex.

$\mathrm{F}$ IG. I. (Plate XI.) reprefents a vertical fection of the elevation of an air-vault 60 feet long and 30 feet wide, confifting of four arches of regularly progrefive fizes. This building is generally conftructed under the bridgehoufe, where the materials are daily collected for filling the furnace. AB, reprefents the acclivity to the furnace top. The fpace betwixt the arch-tops and the level of the foor is filled with matefials as denfe as can be procured. The walls of the under 
Fig. 2.
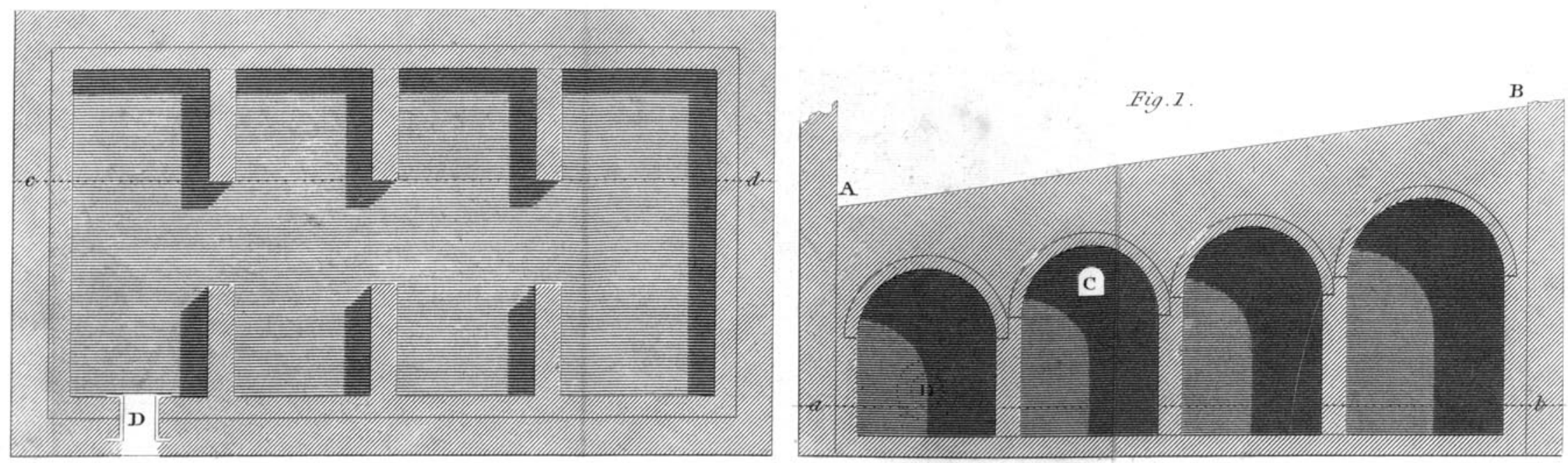

Fig. 4.
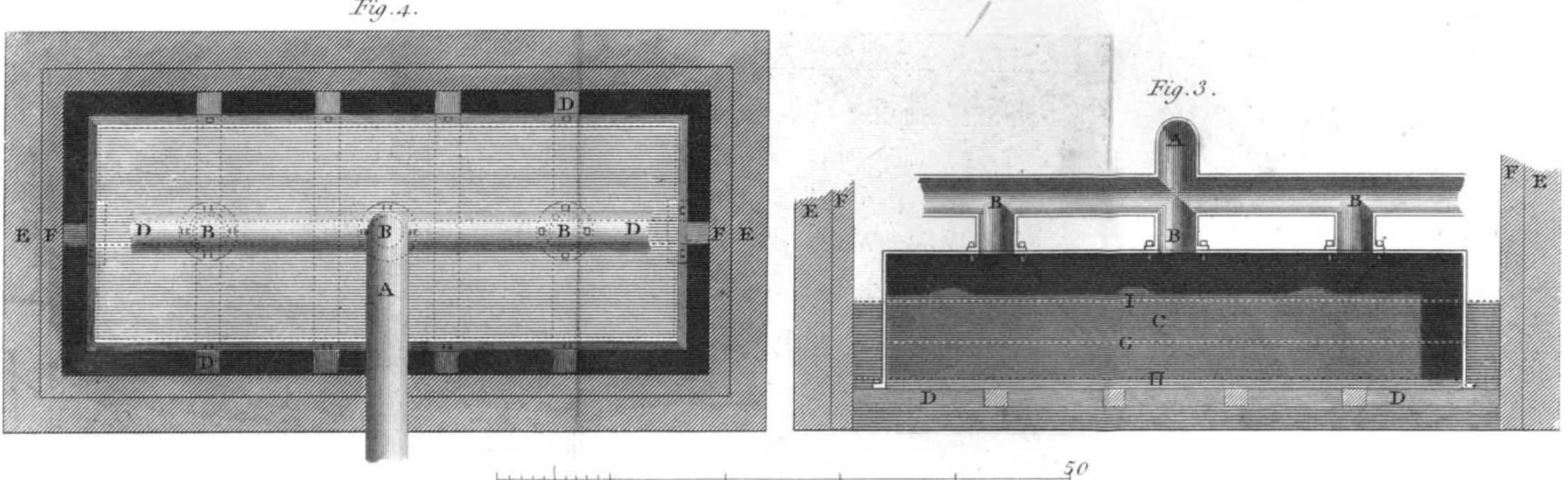

Iowry sculp. 
part are three feet thick, befides a lining of brick and plafter from 18 inches to two feet. Still further precautions are neceffary, and alternate layers of pitch and ftout paper are requifite to prevent the efcape of the compreffed air. C, a view of the arched funnel which conveys the air from the cylinder to the vault. Large iron pipes with a well fitted door are preferable, and lefs apt to emit air. D, an end view of the pipe by which the blaft is carried to the furnace.

Fig. 2. is a horizontal fection of Fig. $x$. at the dotted line $a b$, reprefenting the width of the crofs arches, which are thrown in each partition to preferve an eafy communication betwixt the vaults. D, is a fection of the firft range of pipes, meant to conduct the air to the furnace. In like manner pipes may be taken off from any part of the vault for the different purpofes of blowing furnaces, fineries, hollow fires, \&rc.

Fig. 3. reprefents a vertical longitudinal fection of what is generally called the water-vault. The walls of this building may be erected to the height of eight or nine feet, their thicknefs fimilar to thore of the air-vault. A brick lining, and even puddling with clay betwixt it and the ftone building, is neceffary to prevent the water from oozing by the accumulated preffure. $A$, is an end view of the horizontal range of pipes which conveys the blaft from the blowing cylinder to the inverted chett. BBB, the range which conducts the air to the interior of the inverted chelt, and conveys it to the furnaces, proceeding along the extremities of the columns broken off at BB. C, an inverted cheft made of wood, iron, or even of well-hewn hags fet on end and tightly cemented, is 54 feet within in length, 18 feet wide, and 12 feet high. The dimenfions, however, vary at different works. When the cheft is made of wood or iron, it is generally bolted by means of a flange to the logs on which it is fupported, left the great preffure of air thould overcome the gravitation of the cheft, and difplace it. $D D$, view of the centre $\log$, and ends of the crofs logs, on which the cheft is laid. Thefe fhould meafure 18 inches in height, fo as that the mouth of the cheft may be that difance from the furface of the floor, and the water allowed to retreat from the interior of the cheft with the leaft poffible obftruction. EE, the out- 
fide walls of the building. FF, the brick-work, made perfectly water tight. The dotted line $G$, reprefents the furface of the water when at rett. Let the depth of the water, outfide and inficle of the clyeft, be eftimated at four feet. When the engine is at work, flould the preflure of the air have forced the water down to the dotted line $H$, 3 ! feet diftant from the line $G$, and only fix inches from the mouth of the chelt, it follows, that the water mult have rifen in the outer building, or chef, $3_{2}^{x}$ fect above $G$, and have its bighet furface nearly at reft at $I$. In this cafe the ftrength of the blaft is reckoned equal to feven feet of water, or nearly fix inches of mercury. The fpace betwixt the cheft and outfide builling is three feet. When the engine is at reft, and the water has aftmed its level, the quantity of water within the chelt fhould be equal to that withont.

Fig. 4. is a ground plan of Fig. 3. The crofs logs on which the cifeen is fupported are dotted within, but drawn full in the fpace betwixt the flange of the cheit and outer building. The breadth of the flange-tops of the binding bolts, and thickncfs of the metal of the cheft, are alfo drawn. The letters bear a reference to thofe in No. 3 .

\section{NEW PUBLICATIONS.}

The Clomial Pocket-Book, or Mimoranda Chimica; arranged in a Comperdintm of Chomifly according to the

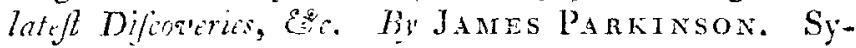
monds; Nurray and Highley, \&c. 230 Pages: 12 mo. Price $5 \mathrm{~s}$.

N a plan of gencral arrangement, nearly fimilar to thofe of Fourcroy and Chaptal, Mr. Parkinfon has brought together, in this little volume, almoft all the priniples, fatts, affirmations and theories of modern chemitiry. If we could be content with an afiemblage of facts, not wrought into regular fyftem, nor prefented in continuous compofition, few bate chemical publications would deferve to be preferred to whis enc. In forming it, the compiler has laid under contribution 